\title{
Evaluation of fine aggregates from the Budhi Gandaki-Narayani River, central Nepal for mortar and concrete
}

\author{
Ajay Babu Nayaju and *Naresh Kazi Tamrakar \\ Central Department of Geology, Tribhuvan University, Kirtipur, Kathmandu, Nepal \\ *Corresponding author: nktam555@gmail.com
}

\begin{abstract}
Huge amounts of construction materials are required to fulfill construction works, which are being undertaken by local and Government levels. In this regard, searching for good quality construction materials is a tough job. The Budhi Gandaki-Narayani River is rich in carrying natural fine aggregates from the Higher and the Lesser Himalayas, which are extensively exposed along its bank. Currently ongoing and future hydro power projects, will require a tremendous amount of fine aggregates. In light of this, the present study was made to evaluate fine aggregates of the Budhi Gandaki-Narayani River. The gradation curves of fine aggregates from this river varied from well graded to uniform graded. Compositional analysis shows that quartz is dominant over other minerals. Rock fragments are composed of gneiss, schist, quartzite, metasandstone, phyllite, shale, granite, etc. Deleterious materials excluding organic matter range from $0.3 \%$ to $1.5 \%$ and organic matter present in range from $0.57 \%$ to $1.11 \%$. The trend of presence of inorganic deleterious material and organic matter is increasing towards southern segments of the river, but they remain below $2 \%$. Mean roundness of particles ranges from 1.88 to 2.54 . Bulk dry density of fine aggregate is below $2 \mathrm{gm} / \mathrm{cm}^{3}$. Similarly, the specific gravity ranges between 1.49 and 1.79. Fineness modulus ranges between 1.36 and 3.50 showing that, coarse, medium, fine and very fine sediments are distributed along the stretch of river. Water absorption value of fine aggregate ranges from $0.48 \%$ to $2.87 \%$. When using fine aggregates from southern segments of the Budhi Gandaki-Narayani River, reduction of mica and beneficiation process will enhance and provide better result for smooth plastering, rendering and screeding.
\end{abstract}

Keywords: Construction material, Gradation analysis, Physical properties, Textural analysis, mortar

Paper Received: 14 Dec 2018

Paper Accepted: 27 Mar 2019

\section{INTRODUCTION}

Fine aggregates are in demand worldwide for growing cities from residential and commercial to municipal construction works for general purpose masonry, wall plastering, rendering, floor screed, paving road, and so on. Many construction projects require fine aggregate as one of the ingredients for concrete and mortar. Naturally occurring fine aggregates are regarded as good resources of the Budhi Gandaki-Narayani River. They have been quarried from this river for more than decades, to supply for various construction works in the nearer districts. Since, natural fine aggregates are widely exposed along banks and bars of the Budhi Gandaki-Narayani River, they have become perfect sites for quarrying aggregates. However, quality of aggregates, which are used in masonry, plastering, screeding and rendering is of great concern.

Maharjan and Tamrakar (2007) evaluated quality of the river gravel from the Rapati River and the Narayani River, and concluded that the majority of gravels of both rivers were of high roundness and high sphericity, and were compositionally sound with good workability for road and concrete aggregates. Similarly, Tamrakar (2011a) evaluated fine aggregates of the Kaligandaki River concluding that the deleterious constituents present in those fine aggregates; mica (8.14\%) and silt/clay $(4.32 \%)$, were detrimental to the soundness of aggregates.
Excessive presence of micas not only complicates workability during placement but also creates a pop-out failure. Smith and Collis (1993) identified main factors influencing aggregate behaviour in various operational and environmental conditions, and concluded that, "the performance of aggregates depends upon their intrinsic properties i.e. the particle shape, grading, composition and their physical and mechanical properties'. Galloway (1994) classified the surface texture of aggregate as glassy, smooth, granular, rough, crystalline, and honeycombed. For the best workability, a smooth surface is most desirable, however, for the best bond between aggregate and cement paste, and also for optimum strength, the rough-textured particles are preferred (CCAA, 2007; CCAA, 2008; Dumitru et al., 2015). Therefore, study of physical and textural properties of fine aggregates are very important to evaluate their usefulness in various constructional activities. The main objectives of the present study are to analyse the physical and textural properties of fine aggregates and to evaluate their potential uses in general masonry, plastering, rendering, and floor screeding.

\section{LOCATION AND DESCRIPTION OF THE STUDY AREA}

The study sites lie within the longitude $84^{\circ} 52^{\prime} 31.01^{\prime \prime} \mathrm{E}$ to latitude $28^{\circ} 13^{\prime} 31.01^{\prime \prime} \mathrm{N}$ and longitude $84^{\circ} 09^{\prime} 06.28^{\prime \prime} \mathrm{E}$ to 
latitude $27^{\circ} 33^{\prime} 84.46^{\prime \prime} \mathrm{N}$ (Fig.1) along the stretch of the Budhi Gandaki-Narayani River. The topography of the study area covers two major physiographic divisions, the hills and valley floor. Towards north the topography of the study area is characterized by steep rouged dissected landforms with high relief, steep slope ridge, rugged terrain, covered by forest. But in south, topography is completely different, dominated by flood plain areas, alluvial fans and terraces. The river channels are small and narrow with valley on the mountainous terrain while in the plain, the channels widen and water depth becomes

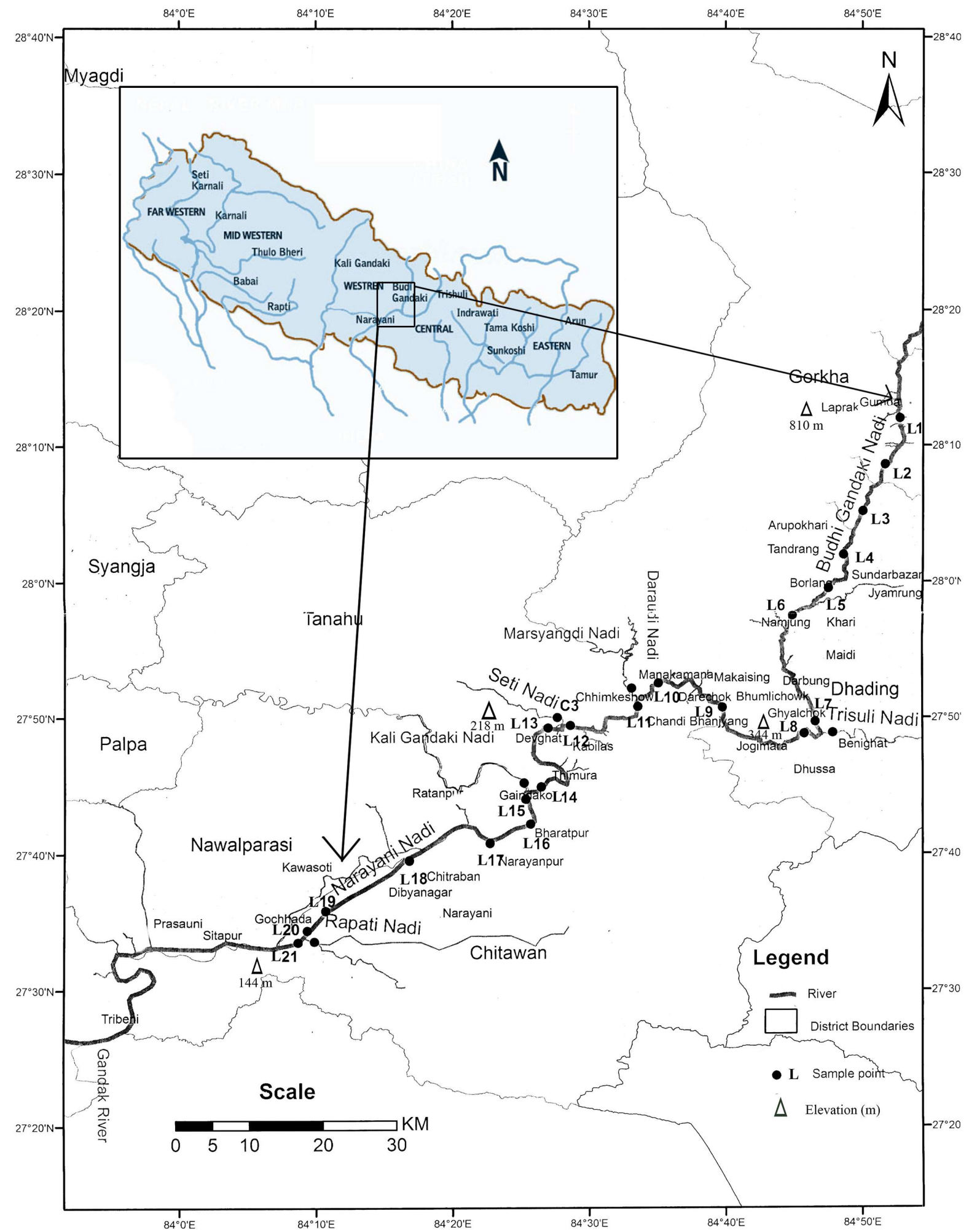

Fig. 1: Location map showing the sampling site of the study area 
shallow showing the characteristic of meandering. In the northern area (Macchakholagau), the Budi Gandaki River flows along the Border line between the Gorkha and the Dhading Districts. Along the downstream course, the Budhi Gandaki River meets the Trishuli River at Benighat. Further downstream, the Marshyandi River merges with the Trishuli River at Muglin, and the Seti and the Kali Gandaki Rivers merge with the Trishuli River, respectively at Devghat and Gaindakot, and the merge out mainstem river becomes the Narayani River. The confluence of the Rapati River and the Narayani River in Meghauli separates the Nawalparsi District at the west from the Chitwan District at the east. Most of the sites are linked with the Prithvi Rajmarga and the Narayanghat-Muglin Highway, and the north of the study area is accessible through feeder roads.

\section{GEOLOGICAL SETTING}

The study area almost comprises of the Midland Group (Fig. 2). The Midland Group is divisible into the Lakharpata

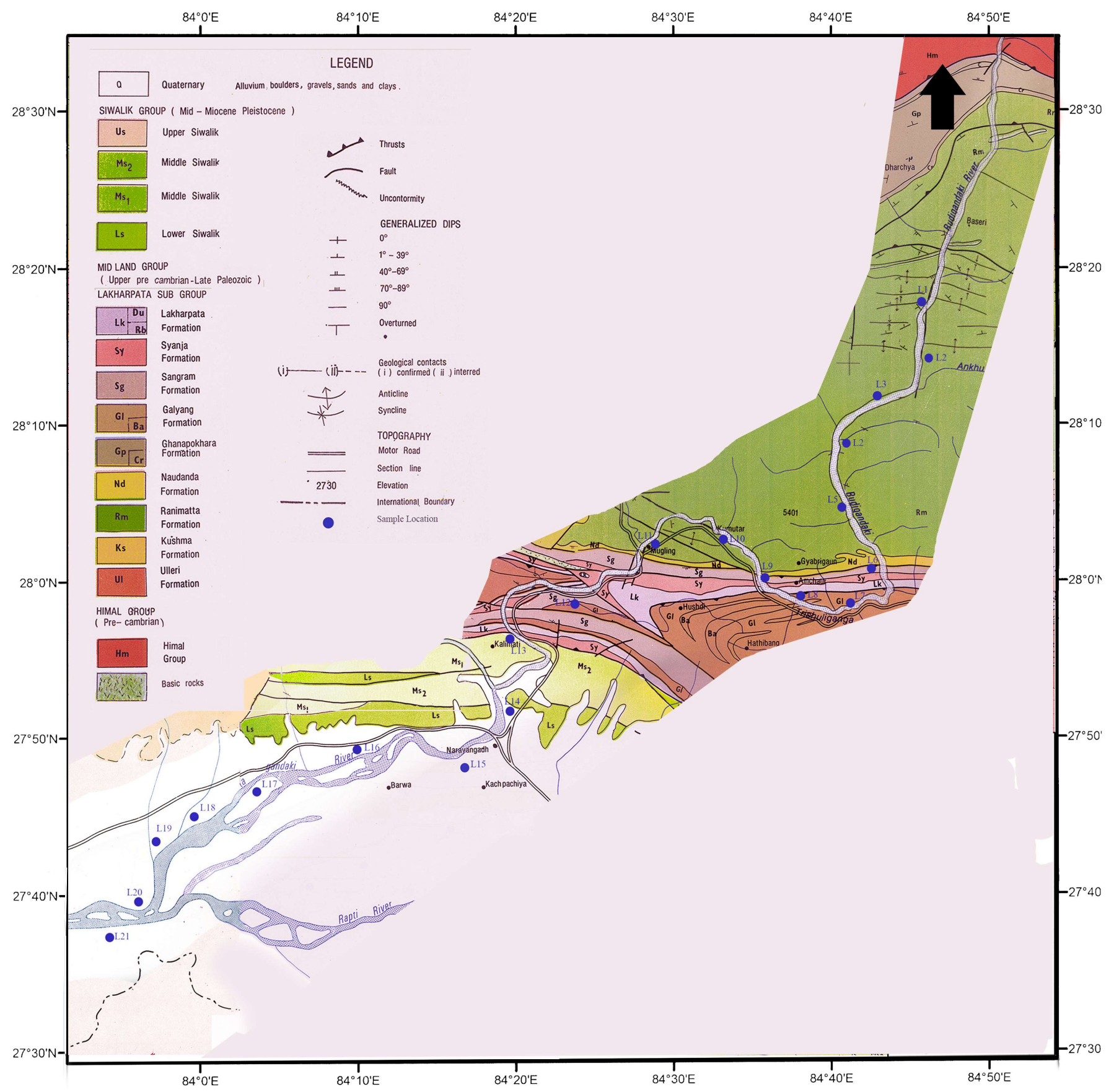

Fig. 2: Geology of the study area (After DMG, 1980) 
Table 1: Showing information of the sampling sites

\begin{tabular}{|c|c|c|c|c|c|c|}
\hline $\begin{array}{l}\text { Sample } \\
\text { No. }\end{array}$ & $\begin{array}{l}\text { Sampling } \\
\text { Location }\end{array}$ & $\begin{array}{l}\text { Distance from source of the } \\
\text { Budhi Gandaki River (km) }\end{array}$ & $\begin{array}{l}\text { Elevation } \\
\quad(\mathrm{m})\end{array}$ & Latitude & Longitude & $\begin{array}{l}\text { Sampling } \\
\text { site }\end{array}$ \\
\hline L1 & Macchakholagau & 67.62 & 810 & $28^{\circ} 13^{\prime} 31.01^{\prime \prime} \mathrm{N}$ & $84^{\circ} 52^{\prime} 31.08^{\prime \prime} \mathrm{E}$ & Side bar \\
\hline $\mathrm{L} 2$ & Soti & 78.28 & 611 & $28^{\circ} 08^{\prime} 14.88^{\prime \prime} \mathrm{N}$ & $84^{\circ} 51^{\prime} 22.61^{\prime \prime} \mathrm{E}$ & side bar \\
\hline L3 & Arukhet Bazar & 83.79 & 542 & $28^{\circ} 05^{\prime} 40.18^{\prime \prime} \mathrm{N}$ & $84^{\circ} 50^{\prime} 10.54^{\prime \prime} \mathrm{E}$ & point bar \\
\hline $\mathrm{L} 4$ & Arughat Bazar & 90.77 & 483 & $28^{\circ} 02^{\prime} 19.41^{\prime \prime} \mathrm{N}$ & $84^{\circ} 48^{\prime} 33.56^{\prime \prime} \mathrm{E}$ & Mid bar \\
\hline L5 & Salantar & 94.24 & 459 & $28^{\circ} 00^{\prime} 39.01^{\prime \prime} \mathrm{N}$ & $84^{\circ} 48^{\prime} 44.72^{\prime \prime} \mathrm{E}$ & point bar \\
\hline L6 & Borlang & 108.95 & 390 & $27^{\circ} 55^{\prime} 49.38^{\prime \prime} \mathrm{N}$ & $84^{\circ} 44^{\prime} 09.80^{\prime \prime} \mathrm{E}$ & Side bar \\
\hline $\mathrm{L} 7$ & Khari & 124.95 & 343 & $27^{\circ} 48^{\prime} 57.90^{\prime \prime} \mathrm{N}$ & $84^{\circ} 46^{\prime} 52.90^{\prime \prime} \mathrm{E}$ & Side bar \\
\hline L8 & Namjung & 126.9 & 344 & $27^{\circ} 48^{\prime} 51.10^{\prime \prime} \mathrm{N}$ & $84^{\circ} 46^{\prime} 12.56^{\prime \prime} \mathrm{E}$ & Side bar \\
\hline L9 & Maidi & 142.85 & 281 & $27^{\circ} 50^{\prime} 38.49^{\prime \prime} \mathrm{N}$ & $84^{\circ} 39^{\prime} 43.00^{\prime \prime} \mathrm{E}$ & point bar \\
\hline L10 & Ghyalchock & 153.95 & 253 & $27^{\circ} 52^{\prime} 44.35^{\prime} \mathrm{N}$ & $84^{\circ} 35^{\prime} 30.01^{\prime \prime} \mathrm{E}$ & Side bar \\
\hline $\mathrm{L} 11$ & Benighat & 158.51 & 244 & $27^{\circ} 51^{\prime} 21.37^{\prime \prime} \mathrm{N}$ & $84^{\circ} 33^{\prime} 29.08^{\prime \prime} \mathrm{E}$ & Side bar \\
\hline $\mathrm{L} 12$ & Jogimare & 171.7 & 229 & $27^{\circ} 49^{\prime} 12.55^{\prime \prime} \mathrm{N}$ & $84^{\circ} 27^{\prime} 56.11^{\prime \prime} \mathrm{E}$ & Side bar \\
\hline L13 & Darechock & 172.93 & 218 & $27^{\circ} 49^{\prime} 15.23^{\prime \prime} \mathrm{N}$ & $84^{\circ} 27^{\prime} 17.47^{\prime \prime} \mathrm{E}$ & Side bar \\
\hline L14 & Kurintar & 190.18 & 190 & $27^{\circ} 44^{\prime} 29.93^{\prime \prime} \mathrm{N}$ & $84^{\circ} 25^{\prime} 35.70^{\prime \prime} \mathrm{E}$ & Side bar \\
\hline L15 & Mugling & 195.43 & 182 & $27^{\circ} 42^{\prime} 02.06^{\prime \prime} \mathrm{N}$ & $84^{\circ} 25^{\prime} 23.55^{\prime \prime} \mathrm{E}$ & Side bar \\
\hline L16 & Bhorle & 200.84 & 181 & $27^{\circ} 40^{\prime} 43.85^{\prime \prime} \mathrm{N}$ & $84^{\circ} 22^{\prime} 36.90^{\prime \prime} \mathrm{E}$ & Side bar \\
\hline L17 & Dashdhunga & 216.08 & 164 & $27^{\circ} 38^{\prime} 4.34^{\prime \prime} \mathrm{N}$ & $84^{\circ} 15^{\prime} 56.26^{\prime \prime} \mathrm{E}$ & Side bar \\
\hline L18 & Jugedi Bazar & 221.13 & 158 & $27^{\circ} 36^{\prime} 45.61^{\prime \prime} \mathrm{N}$ & $84^{\circ} 13^{\prime} 15.39^{\prime \prime} \mathrm{E}$ & Side bar \\
\hline L19 & Devghat & 22.91 & 150 & $27^{\circ} 35^{\prime} 37.00^{\prime \prime} \mathrm{N}$ & $84^{\circ} 11^{\prime} 35.91^{\prime \prime} \mathrm{E}$ & Side bar \\
\hline $\mathrm{L} 20$ & Narayangadh & 227.57 & 146 & $27^{\circ} 34^{\prime} 42.28^{\prime \prime} \mathrm{N}$ & $84^{\circ} 10^{\prime} 23.24^{\prime \prime} \mathrm{E}$ & Side bar \\
\hline L21 & Meghauli & 230.45 & 144 & $27^{\circ} 33^{\prime} 38.46^{\prime \prime} \mathrm{N}$ & $84^{\circ} 09^{\prime} 06.28^{\prime \prime} \mathrm{E}$ & Side bar \\
\hline
\end{tabular}

Subgroup and the Dailekh Subgroup (DMG, 1987). Lakharpata Subgroup comprises of the Galyang Formation, Sangram Formation, Syangja Formation and the Lakharpata Formation. The Dailekh Subgroup comprises of the Ulleri Formation, Kushma Formation, Ranimatta Formation, Naudada Formation and the Ghanapokhari Formation from older to younger sequence. Most dominant formation observed in the field was the Ranimatta Formation. The Budhi Gandaki River flows, throughout the Ranimatta Formation, composed of greenish grey gritty phyllite, gritstone with conglomerate and white massive quartzite, is mostly exposed along the banks of the river. In the downstream portion of the river at Borlang, the Naudanda Formation consists of white, massive, and fine- to medium-grained quartzite. Further south, the Sangram Formation consists of black, dark grey to greenish grey shale with intercalation of limestone and quartzite. The Syangja Formation consists of white pale orange or purple calcareous quartzite and quartzitic limestone intercalated with dark grey purple and green shale with strongly ripple marked quartzite at the base. The Larkharpata Formation is composed of fine-grained, bluish grey limestone and dolomite with thin intercalation of grey shales, pink dolomitic limestone, purple quartzite and green shale at the top. The Galyang Formation consists of black to grey carbonaceous slates and green shale. Further south the Syangja Formation and the Middle Siwaliks are separated by the Main Boundary Thrust, and are distinguished by the variation in lithological change from metamorphic to sedimentary rocks in Narayangadh and Meghauli (DMG, 1987). The Middle Siwaliks are underlain by the Lower Siwaliks in further south of the area. The Lower Siwaliks consist of finegrained, grey sandstones interblended with purple and brown shale, nodular maroon clays and pseudo conglomerate. Medium- to coarse-grained sandstones, pebbly sandstone, and occasionally fine-grained sandstone and conglomerate are observed in the Middle Siwaliks. The Quaternary alluvial deposits of boulder, gravel and clay are distinctly observed in Meghauli, which is a confluence of the Rapati River and the Narayani River.

\section{MATERIAL AND METHODS}

About 700 grams of sample were collected from 21 sampling sites along the stretch of the river from the Macchakholagau to Meghauli (Table 1) for further lab analysis of composition, texture and physical properties.

Samples were washed and dried in oven for 24 hours at constant temperature $70^{\circ} \mathrm{C}$. After that they were stained for feldspars (Tamrakar, 2011b). Then the grain mounts of sample were visualized under the binocular stereomicroscope for composition. Deleterious material was calculated by following the designation IS 2688 (1977)

\section{Deleterious material $(\%)=(\mathrm{W} 1+\mathrm{W} 2+\mathrm{W} 3+\mathrm{W} 4) / \mathrm{WT}$}

Where, W1 is mass of clay lump, W2 is mass of shale, W3 is mass of wood fragment, W4 is mass of coal and WT is total dry mass.

Dichromate oxidation method was used to determine the organic content. This method was first introduced by Walkey and Black in 1934, and later revised by Walkey in 1935 (BS 1377, 1975). About 5 grams of air-dried sample was mixed with $10 \mathrm{ml}$ potassium dichromate $1 \mathrm{~N}$ solution and $10 \mathrm{ml}$ sulphuric acid then left for cooling half hour. After that, $200 \mathrm{ml}$ distilled water and $10 \mathrm{ml}$ orthophospheric acid was added with $1 \mathrm{ml}$ 
indicator NaF. Finally, titration was done adding $0.5 \mathrm{ml}$ ferrous sulphate and $0.5 \mathrm{ml}$ potassium dichromate by changing the color from blue to green.

\section{Organic matter $=[\{(\mathrm{B}-\mathrm{T}) \mathrm{N}\} / \mathrm{M}] 0.76$}

where, $\mathrm{B}$ is the amount of ferrous sulphate required in blank titration, $\mathrm{T}$ is the amount of ferrous sulphate required in sample titration, $\mathrm{N}$ is the strength of ferrous sulphate required in blank titration $(0.5 \mathrm{~N})$ and $\mathrm{M}$ is the amount of sample taken.

Designation ASTM C136-06 (2006) was followed for sieve analysis. Firstly, the fine aggregates were dried and then sieved. Fineness modulus of the sample was also calculated to determine the coarseness and fineness of the sample. To calculate the fineness modulus (FM), the sum of the cumulative percentage retained on a specified set of sieves was determined, and the obtained result was divided by 100 .

The shape of the constituents of fine aggregates was assessed by visual estimation of roundness.

Mean roundness $=\operatorname{SUM}(\mathrm{mi}$. fi $) / \mathrm{SUM}(\mathrm{F})$

where, mi is the mid value of each of the six roundness classes, fi is the frequency observed in each class and $\mathrm{F}$ is the total frequency of grains observed.

The physical properties such as dry density, specific gravity and water absorption was determined following the designation ASTM C127 (2001). Samples were immersed in water for 24 hours, then surface dried, weighed and percentage absorption relative to dry was calculated.

Water Absorption $(\%)=[(\mathrm{B}-\mathrm{A}) / \mathrm{A}] \mathrm{x} 100$
Where, $\mathrm{A}=$ Weight of oven dried sample, and $\mathrm{B}=$ Weight of the saturated surface-dry (SSD) sample.

Specific gravity (SG) is a mass of a given substance divided by unit mass of an equal volume of water. Depending on the moisture condition, specific gravity can be oven dried, or saturated surface-dry. Apparent specific gravity (ASG) is defined as the ratio of density of the particles to the density of the water.

$$
\begin{aligned}
& \text { Dry specific gravity }=\mathrm{A} /(\mathrm{B}+\mathrm{S}-\mathrm{C}) \\
& \text { SSD specific gravity }=\mathrm{S} /(\mathrm{S}-\mathrm{C}-\mathrm{B}) \\
& \text { Apparent specific gravity }=\mathrm{A} /(\mathrm{A}-\mathrm{C}-\mathrm{B})
\end{aligned}
$$

Dry density $=[\mathrm{A} /(\mathrm{B}+\mathrm{S}-\mathrm{C})]$. Density of water

Where, A is mass of dry sand, B is mass of pycnometer filled with water, $\mathrm{S}$ is mass of saturated surface dry, $\mathrm{C}$ is mass of pycnometer filled with water and sand.

\section{RESULTS}

\section{Composition}

The fine aggregates retained on specific sieves (Table 2) were used for compositional analysis. The fine aggregates from river contain different types of rock fragments. In all sampling location, quartz is the most dominant mineral varying from 51 to $61 \%$ (Table 3 ). Quartz grains of river ranged from sub angular to sub rounded. Fine aggregates were mainly composed of quartz, feldspar, rock fragment, mica and other heavy minerals. From the Macchakholagau to Meghauli, there

\begin{tabular}{|c|c|c|c|c|c|}
\hline Sample No. & $\begin{array}{c}2.36 \mathrm{~mm} \text { retained } \\
(\mathrm{gm})\end{array}$ & $\begin{array}{c}0.6 \mathrm{~mm} \\
\text { Retained }(\mathrm{mm})\end{array}$ & $\begin{array}{c}0.15 \mathrm{~mm} \text { retained } \\
(\mathrm{gm})\end{array}$ & $\begin{array}{c}0.75 \mathrm{~mm} \text { retained } \\
(\mathrm{gm})\end{array}$ & $\begin{array}{l}\text { PAN } \\
(\mathrm{gm})\end{array}$ \\
\hline L1 & 1.66 & 62.49 & 30.73 & 8.83 & 5.23 \\
\hline L2 & 3.00 & 29.00 & 41.97 & 41.25 & 15.65 \\
\hline L3 & 3.81 & 37.62 & 47.34 & 15.72 & 2.04 \\
\hline $\mathrm{L} 4$ & 5.37 & 40.19 & 26.47 & 23.14 & 13.00 \\
\hline L5 & 1.62 & 21.37 & 54.46 & 48.06 & 16.36 \\
\hline L6 & 8.66 & 33.40 & 39.03 & 28.18 & 14.44 \\
\hline $\mathrm{L} 7$ & 0.32 & 0.32 & 65.00 & 38.28 & 15.34 \\
\hline L8 & 0.12 & 1.08 & 68.00 & 36.63 & 18.06 \\
\hline L9 & 0.67 & 15.01 & 80.04 & 40.81 & 8.00 \\
\hline L10 & 0.28 & 7.26 & 96.04 & 10.65 & 3.84 \\
\hline L1 1 & 6.47 & 20.83 & 57.00 & 7.79 & 3.68 \\
\hline L12 & 12.07 & 50.17 & 13.00 & 11.77 & 7.00 \\
\hline L13 & 7.88 & 17.87 & 57.00 & 14.20 & 16.38 \\
\hline $\mathrm{L} 14$ & 3.30 & 10.33 & 65.07 & 35.30 & 6.70 \\
\hline $\mathrm{L} 15$ & 4.00 & 80.18 & 12.46 & 4.40 & 4.00 \\
\hline L16 & 0.44 & 6.00 & 43.59 & 87.60 & 7.66 \\
\hline $\mathrm{L} 17$ & 2.20 & 7.66 & 91.05 & 17.26 & 13.50 \\
\hline L18 & 0.27 & 3.21 & 90.03 & 47.08 & 5.68 \\
\hline L19 & 0.75 & 2.43 & 83.16 & 74.00 & 34.63 \\
\hline L20 & 3.60 & 4.17 & 68.86 & 43.32 & 48.00 \\
\hline $\mathrm{L} 21$ & 3.61 & 5.73 & 80.67 & 17.03 & 14.00 \\
\hline
\end{tabular}
is slightly variation in composition (Fig. 3). The quartz content

Table 2: Weight of sample retained on specified sieve 
Table 3: Composition of fine aggregates

\begin{tabular}{|c|c|c|c|c|c|c|c|c|c|}
\hline \multirow[t]{2}{*}{ S. N. } & \multirow{2}{*}{$\begin{array}{c}\text { Quartz } \\
\%\end{array}$} & \multirow{2}{*}{$\begin{array}{c}\text { Feldspar } \\
\%\end{array}$} & \multirow{2}{*}{$\begin{array}{c}\text { Mica } \\
\%\end{array}$} & \multicolumn{3}{|c|}{ Rock fragments $\%$} & \multirow{2}{*}{$\begin{array}{l}\text { Heavy } \\
\text { mineral }\end{array}$} & \multirow{2}{*}{$\begin{array}{c}\text { wood } \\
\text { Fragment }\end{array}$} & \multirow{2}{*}{$\begin{array}{c}\text { Total } \\
\%\end{array}$} \\
\hline & & & & Met. rock & Sed. rock & Ign. rock & & & \\
\hline L1 & 61.03 & 8.39 & 13.77 & 5.15 & 2.49 & 4.56 & 4.75 & 1.15 & 100 \\
\hline $\mathrm{L} 2$ & 60.19 & 8.82 & 13.72 & 5.64 & 1.86 & 4.39 & 4.56 & 1.42 & 100 \\
\hline L3 & 59.18 & 9.10 & 14.05 & 4.87 & 1.74 & 3.98 & 5.38 & 2.38 & 100 \\
\hline L4 & 60.01 & 9.54 & 12.93 & 4.47 & 2.35 & 4.25 & 5.44 & 2.40 & 100 \\
\hline L5 & 57.77 & 8.82 & 16.27 & 5.03 & 1.75 & 4.20 & 3.71 & 2.68 & 100 \\
\hline L6 & 58.99 & 9.40 & 17.48 & 4.30 & 2.36 & 3.62 & 3.79 & 3.32 & 100 \\
\hline L7 & 55.55 & 9.80 & 16.15 & 3.94 & 3.44 & 4.24 & 4.02 & 3.61 & 100 \\
\hline L8 & 57.85 & 9.58 & 17.04 & 3.75 & 2.56 & 3.32 & 3.18 & 4.02 & 100 \\
\hline L9 & 56.80 & 8.40 & 16.97 & 4.93 & 2.34 & 3.95 & 3.72 & 3.68 & 100 \\
\hline L10 & 54.88 & 8.38 & 17.34 & 4.91 & 3.53 & 4.50 & 3.53 & 4.95 & 100 \\
\hline L11 & 55.05 & 9.98 & 18.71 & 4.67 & 2.18 & 3.39 & 2.69 & 4.67 & 100 \\
\hline L12 & 52.12 & 8.48 & 19.94 & 5.13 & 3.34 & 4.17 & 2.83 & 4.28 & 100 \\
\hline L13 & 54.59 & 9.61 & 19.84 & 3.74 & 1.90 & 4.48 & 2.09 & 4.28 & 100 \\
\hline L14 & 54.23 & 9.56 & 20.08 & 4.37 & 2.11 & 4.26 & 2.28 & 4.69 & 100 \\
\hline L15 & 53.41 & 10.62 & 20.30 & 3.88 & 1.55 & 3.69 & 2.72 & 5.05 & 100 \\
\hline L16 & 55.31 & 9.71 & 19.76 & 3.68 & 2.42 & 3.87 & 2.88 & 4.37 & 100 \\
\hline L17 & 53.35 & 8.27 & 20.62 & 3.63 & 3.40 & 4.06 & 3.08 & 4.85 & 100 \\
\hline L18 & 54.01 & 8.77 & 20.40 & 4.20 & 2.35 & 3.55 & 2.36 & 5.27 & 100 \\
\hline L19 & 52.21 & 9.70 & 21.02 & 3.22 & 3.09 & 3.36 & 3.21 & 5.59 & 100 \\
\hline L20 & 51.04 & 10.53 & 20.80 & 3.79 & 3.38 & 3.90 & 2.50 & 5.29 & 100 \\
\hline L21 & 52.72 & 10.68 & 19.66 & 3.30 & 3.14 & 3.39 & 2.98 & 5.50 & 100 \\
\hline
\end{tabular}

fluctuates and finally diminishes downstream. Similarly, the content of mica percentage (13.77\% to $20.02 \%$ ) is in increasing trend. Percentage Mica is very low at the source of the river but it is continuously increasing towards south. Likewise, the percentage of feldspar ranges from $8 \%$ to $10 \%$. Total average rocks fragments of metamorphic, igneous and sedimentary are also present in the range from $3.28 \%$ to $4.21 \%$ (Table 3). Heavy minerals like iron, garnet and tourmaline are mostly present ( $2 \%$ to $4 \%$ ) in the northern sites. The percentage of wood fragment varies from $1.15 \%$ in Macchakholagau to $5.50 \%$ in Meghauli, Chitwan. While travelling downstream, dominantly light minerals are carried by the river.

\section{Deleterious materials}

Deleterious constituents are listed in Table 4. Silts and clay (passing from $0.075 \mathrm{~mm}$ ) are considered as the fine materials. The presence of fines in excessive amount is not good for the construction purpose. The percent fines present in the sample range from $1.02 \%$ to $24.0 \%$ (Table 4). Location 20 (Table 4) has the highest percent of fines among the whole sampling location. The excessive fines prevent bonding between cement and aggregates. According to ASTM C33-03, fines percentage limit up to $7 \%$ is good for constructional purpose. Similarly, the mica present in the sample range $13.77 \%$ to $20.02 \%$ (Table
4). Presence of mica in sand affects the strength and bonding with cement (Fookers and Revie, 1982) and brings the problem known to occur with surface finishes related to 'shelling out' (particle popping out). High mica content tends to absorb water in the mixture of sand and cement. British Standard Institution

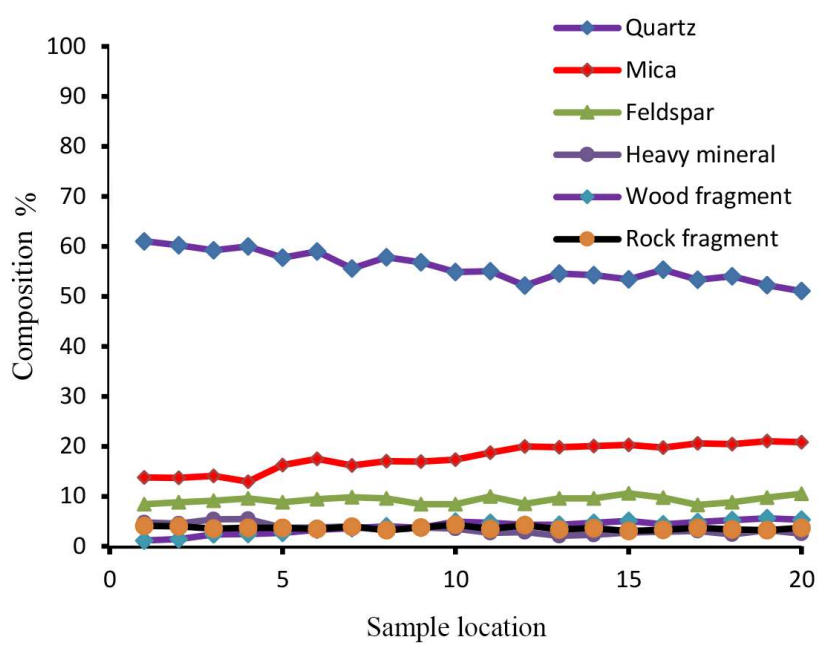

Fig. 3: Downstream variation of constituents of fine aggregates 
Table 4: Deleterious constituents in fine aggregates from the Budhi Gandaki-Narayani River

\begin{tabular}{ccccc}
\hline S. N. & $\begin{array}{c}\text { Fines } \\
(<0.075 \mathrm{~mm}) \\
\%\end{array}$ & $\begin{array}{c}\text { Mica } \\
\text { index } \\
(\%)\end{array}$ & $\begin{array}{c}\text { Wood } \\
\text { fragment } \\
(\%)\end{array}$ & $\begin{array}{c}\text { Organic } \\
\text { matter } \\
(\%)\end{array}$ \\
\hline L1 & 2.62 & 13.77 & 1.15 & 0.57 \\
L2 & 7.82 & 13.72 & 1.42 & 0.60 \\
L3 & 1.02 & 14.05 & 2.38 & 0.64 \\
L4 & 6.50 & 12.93 & 2.40 & 0.64 \\
L5 & 8.18 & 16.27 & 2.68 & 0.65 \\
L6 & 7.22 & 17.48 & 3.32 & 0.67 \\
L7 & 8.17 & 16.15 & 3.61 & 0.70 \\
L8 & 9.03 & 17.04 & 4.02 & 0.74 \\
L9 & 4.00 & 16.97 & 3.68 & 0.75 \\
L10 & 1.92 & 17.34 & 4.95 & 0.77 \\
L11 & 1.84 & 18.71 & 4.67 & 0.79 \\
L12 & 3.50 & 19.94 & 4.28 & 0.84 \\
L13 & 8.19 & 19.84 & 4.28 & 0.87 \\
L14 & 3.35 & 20.08 & 4.69 & 0.90 \\
L15 & 2.00 & 20.30 & 5.05 & 0.92 \\
L16 & 3.83 & 19.76 & 4.37 & 0.95 \\
L17 & 6.75 & 20.62 & 4.85 & 0.97 \\
L18 & 2.84 & 20.40 & 5.27 & 1.01 \\
L19 & 17.31 & 21.02 & 5.59 & 1.04 \\
L20 & 24.00 & 20.80 & 5.29 & 1.06 \\
L21 & 7.00 & 19.66 & 5.50 & 1.11 \\
\hline
\end{tabular}

(BSI) recommends avoiding sands with more than $8 \%$ mica (BSI, 1973). Wood fragments varies from 1.15 to $5.59 \%$. The overall trends of presence of fines, mica and wood fragment are shown in Fig. 4. Increasing trends shown by variation of mica and wood fragments are well explained by increase in downstream distance of the river. The nature of data and trend line shows that, the larger the distance travels by river towards south, greater the amount of deleterious material.

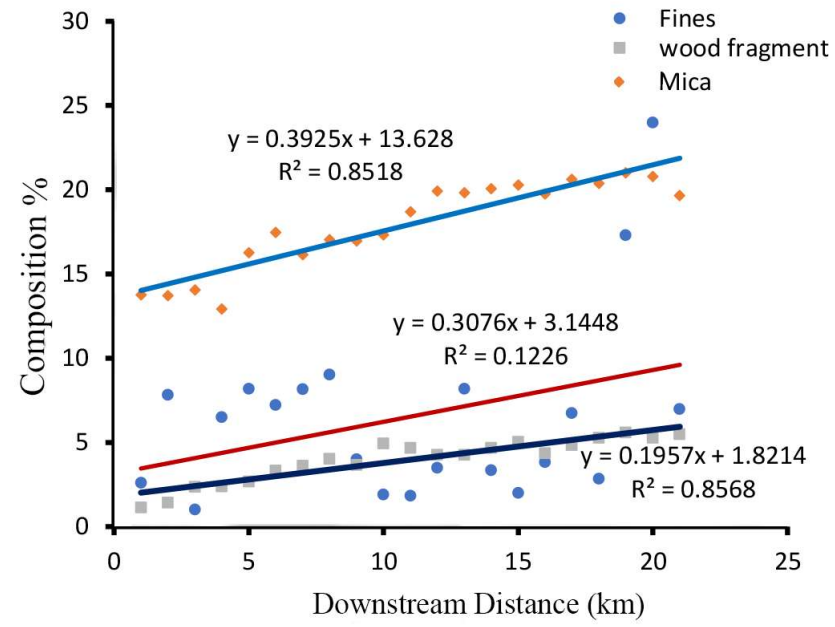

Fig. 4: Downstream variation trends of deleterious constituents in fine aggregates from the Budhi GandakiNarayani River
The presence of organic material in the aggregate will decrease the durability and strength of mortar and concrete by increasing the water demand and reducing the strength bond between aggregates. Organic matter is in upward trend with increasing the distance from the source of origin of river. The Minimum and maximum percentage of organic matter present is in sampling location L1 and L21 respectively which is $0.57 \%$ at the Machhakholagau and $1.11 \%$ at Meghauli.

Most of the organic matter in river comes from the deteriorated material in the water and surrounding shore. Organic matter content varies from 0.57 to $1.11 \%$. It tends to increase along the downstream course of the Budhi Gandaki-Narayani River (Fig. 5). This is perhaps due to the human settlement, agricultural practice, mixing of waste drainage directly into the river and decay of plants and vegetation.

\section{Gradation and Shape Analysis}

The fineness modulus of fine material should lie between 2.3 and 3.1 (ASTM C33, 1994). A small number indicates a fine grading whereas large number indicates a coarse grading. Here, the fineness modulus of the sampling location ranged from 1.36 to 3.50. Fine aggregates near the source of the Budhi Gandaki River have least roundness and sphericity (Table 5). The gradation curve of the respective sampling location is tallied with the upper and lower limit of the different designation specified by BS 1299 (1984) and BS 1199 (1986) .The curves show different nature. In some sampling locations, fine aggregates are excellent for plastering, while in the other sampling locations, fine aggregates are good for rendering and floor screeding.

For the general purpose of sand for mortar, gradation curve of the fine aggregates of every location fall within the recommended range of the upper and the lower limits as per designation of BS 1299 (1984) (Fig. 6). Similarly, for floor screeding (Fig. 7), the gradation curve of the sample locations; L2, L3, L6, L7, L8, L10, L11, L15, L16, L18, L19, and L20

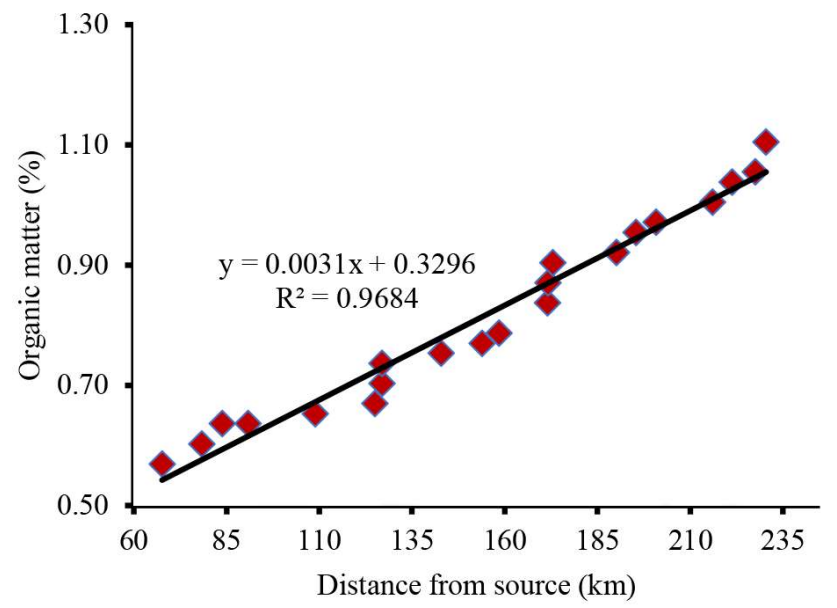

Fig. 5: Downstream variation trends of organic matter content in the fine aggregates from the Budhi GandakiNarayani River 
are within the envelop recommended by BS 1199 (1986). Regarding suitability of the gradation curves for rendering as designation by BS 1199 (1976), most of the curves of the samples L1, L2, L3, L7, L8, L9, L15, L16, L17, L18, L19, and L21 are smooth and lie within the recommended envelop (Fig. 8). Plastering is intended to conceal unevenness in the background and to provide a beautiful finishing that is smooth, crack free, hygienic, resistance to damage and easily decorative. The gradation curves (Fig. 9) of fine aggregate from locations L4, L5, L6, L7, L8, L9, L10, L11, L13, L14, L17, L19, L20, and L21 lie within the acceptable limit envelop for plastering when complying with BS 1199 (1986).

\section{Specific gravity, density and water absorption}

The dry specific gravity of the entire aggregates sample ranges between 1.40 to 1.89 (Table 6) and the dry density ranges from $1.39 \mathrm{gm} / \mathrm{cm}^{3}$ to $1.79 \mathrm{gm} / \mathrm{cm}^{3}$. Similarly, the water absorption (WA) of fine aggregates ranges from $0.47 \%$ to $2.87 \%$. Higher the porosity is, the greater the water absorption. Water absorption is directly proportional to the porosity of the aggregates. Here, sampling location L10 and L20 have the maximum water absorption value. The fine aggregates show low effective porosity therefore there is wide possibility of applicability of these aggregates in construction.

\section{EVALUATION OF FINE AGGREGATES}

Gradation curve of fine aggregates consists of both poorly graded and well graded particles (Table 7). Well graded performance is better than poorly graded sand because poorly graded sands have more void space. Most of the samples belong to dense graded and remaining are well and uniform graded. There is a slightly variation of uses of sand as fine aggregates. Sands from some sampling locations are good for plastering while others are good for screeding, and rendering. For general purpose mortar, sands from all most all the sampling locations lie within the limit range expect for some sites (Table 7), and can give good performance in all construction activities.

Compositional analysis shows that quartz $(>50 \%)$ is the most dominate mineral. Similarly, heavy mineral like garnet, iron oxides, tourmaline, etc. are also present. Mica shows a remarkable amount ranging from $13.77 \%$ to $20.02 \%$. Mica is friable and flaky, and therefore its amount should not be above $5 \%$ as other deleterious material like clay lump, shale, and friable material. Higher amounts of organic matter and other deleterious materials are observed towards the downstream portion of the river. While using such area for sands for mortars and concrete, special treatment like beneficiation must be carried out for durability and better finishing.

The dry specific gravity, dry density and water absorption of samples range respectively from 1.40 to $1.89,1.39 \mathrm{gm} / \mathrm{cm}^{3}$ to $1.79 \mathrm{gm} / \mathrm{cm}^{3}$, and $0.47 \%$ to $2.87 \%$. (Table 6 ). Based on dry density, the upstream few samples (L1 to L4) are usable for heavy as well as normal structures. The samples L5 to L18 are suitable for normal structure mortars and concrete. The samples L19 to L21 at downstream portions of the river are suitable for light weight structures. The WAV most of the sediments sample

Table 5: Result of Gradation and shape analyses of the fine aggregates from the Budhi Gandaki-Narayani River

\begin{tabular}{|c|c|c|c|c|c|c|c|c|c|}
\hline $\begin{array}{l}\text { Sample } \\
\text { No. }\end{array}$ & $\begin{array}{c}\text { Distance from source of Budhi } \\
\text { Gandaki River }(\mathrm{km})\end{array}$ & $\mathrm{Cu}$ & $\mathrm{Cc}$ & Grade & $\begin{array}{l}\text { Gradation } \\
\text { type }\end{array}$ & $\begin{array}{c}\text { Fineness } \\
\text { modulus } \\
(\mathrm{FM})\end{array}$ & $\begin{array}{l}\text { Types } \\
\text { of sand }\end{array}$ & $\begin{array}{l}\text { Mean } \\
\text { Roundness }\end{array}$ & $\begin{array}{c}\text { Mean } \\
\text { sphericity }\end{array}$ \\
\hline $\mathrm{Ll}$ & 67.62 & 0.80 & 0.27 & Poor & Uniform & 3.16 & Coarse & 1.88 & 0.72 \\
\hline $\mathrm{L} 2$ & 78.28 & 5.33 & 0.75 & Poor & Uniform & 2.44 & Fine & 2.34 & 0.71 \\
\hline L3 & 83.79 & 8.00 & 2.00 & Well & Gap & 2.94 & Fine & 2.14 & 0.69 \\
\hline L4 & 90.77 & 7.50 & 1.88 & Well & Gap & 2.12 & Coarse & 2.12 & 0.71 \\
\hline L5 & 94.24 & 4.00 & 1.00 & Poor & Uniform & 2.56 & Fine & 2.09 & 0.71 \\
\hline L6 & 108.95 & 5.60 & 1.40 & Well & Gap & 2.05 & Fine & 2.06 & 0.69 \\
\hline L7 & 124.95 & 4.29 & 1.38 & Poor & Uniform & 2.03 & Fine & 2.36 & 0.72 \\
\hline L8 & 126.9 & 4.00 & 1.44 & Poor & Uniform & 2.19 & Fine & 2.80 & 0.69 \\
\hline L9 & 142.85 & 3.75 & 1.35 & Poor & Dense & 2.41 & Fine & 2.92 & 0.71 \\
\hline L10 & 153.95 & 2.07 & 0.78 & Well & Gap & 3.11 & Coarse & 2.71 & 0.71 \\
\hline L11 & 158.51 & 3.53 & 1.57 & Poor & Dense & 3.49 & Coarse & 2.53 & 0.72 \\
\hline L12 & 171.7 & 2.65 & 1.18 & Well & Gap & 2.77 & Medium & 2.86 & 0.71 \\
\hline L13 & 172.93 & 4.00 & 0.42 & Poor & Uniform & 2.43 & Fine & 2.66 & 0.72 \\
\hline L14 & 190.18 & 3.20 & 1.13 & Poor & Uniform & 3.50 & Coarse & 3.01 & 0.69 \\
\hline L15 & 195.43 & 2.33 & 0.96 & Poor & Dense & 2.94 & Coarse & 1.76 & 0.73 \\
\hline L16 & 200.84 & 2.63 & 0.86 & Poor & Dense & 1.82 & V. Fine & 2.86 & 0.71 \\
\hline $\mathrm{L} 17$ & 216.08 & 2.31 & 1.03 & Poor & Dense & 2.44 & Fine & 2.62 & 0.69 \\
\hline L18 & 221.13 & 2.50 & 1.30 & Poor & Dense & 2.01 & Fine & 2.72 & 0.71 \\
\hline L19 & 22.91 & 1.83 & 0.38 & Poor & Dense & 1.36 & V. Fine & 2.88 & 0.71 \\
\hline L20 & 227.57 & 1.30 & 0.93 & Poor & Uniform & 1.77 & V. Fine & 2.44 & 0.69 \\
\hline L21 & 230.45 & 2.38 & 0.99 & Poor & Dense & 2.48 & Fine & 2.54 & 0.71 \\
\hline
\end{tabular}



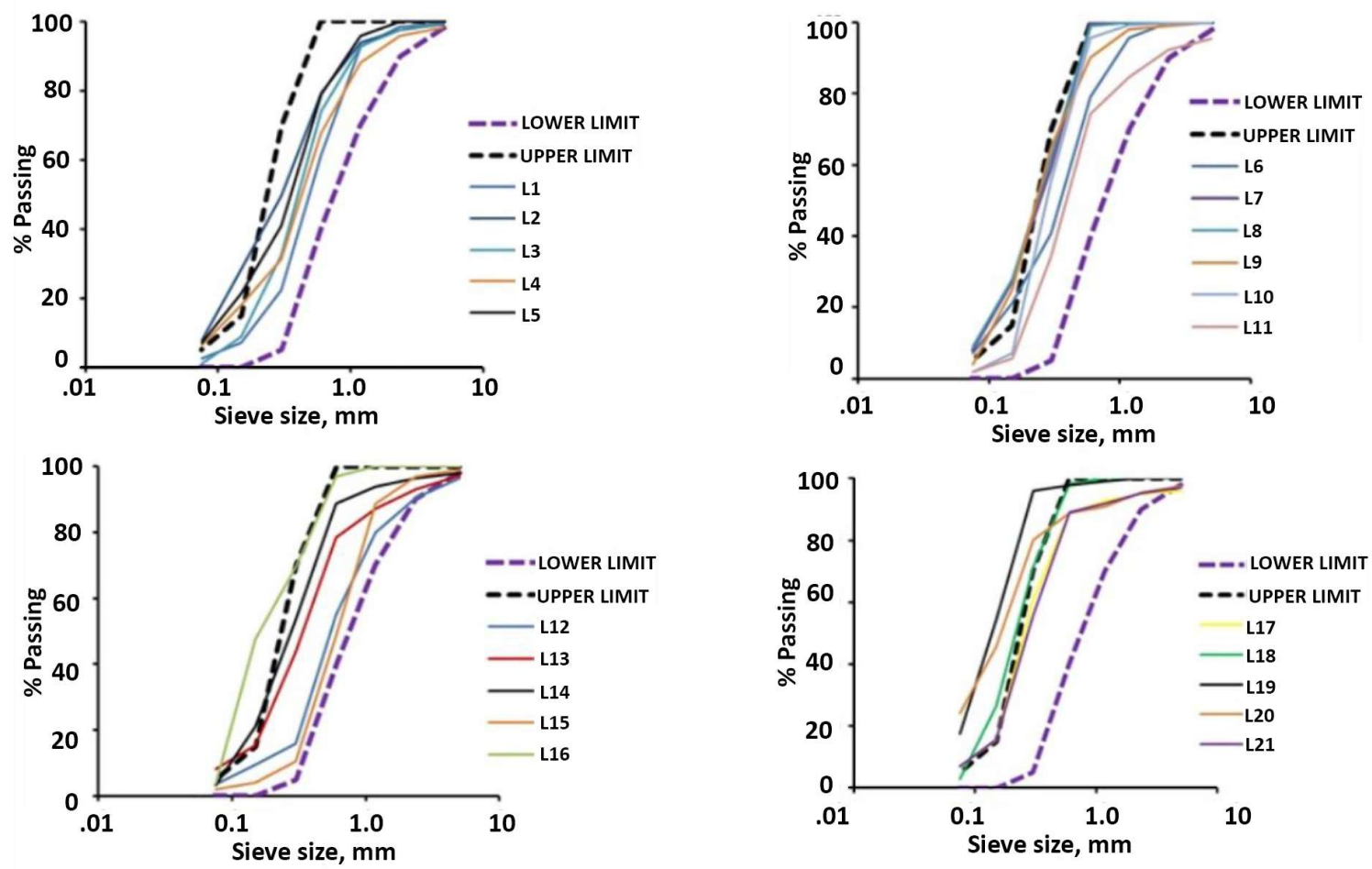

Fig. 6: Grain size distribution of fine aggregates from the Budhi Gandaki-Narayani River compared for general purpose with the gradation curve of BS 1299 (1984)
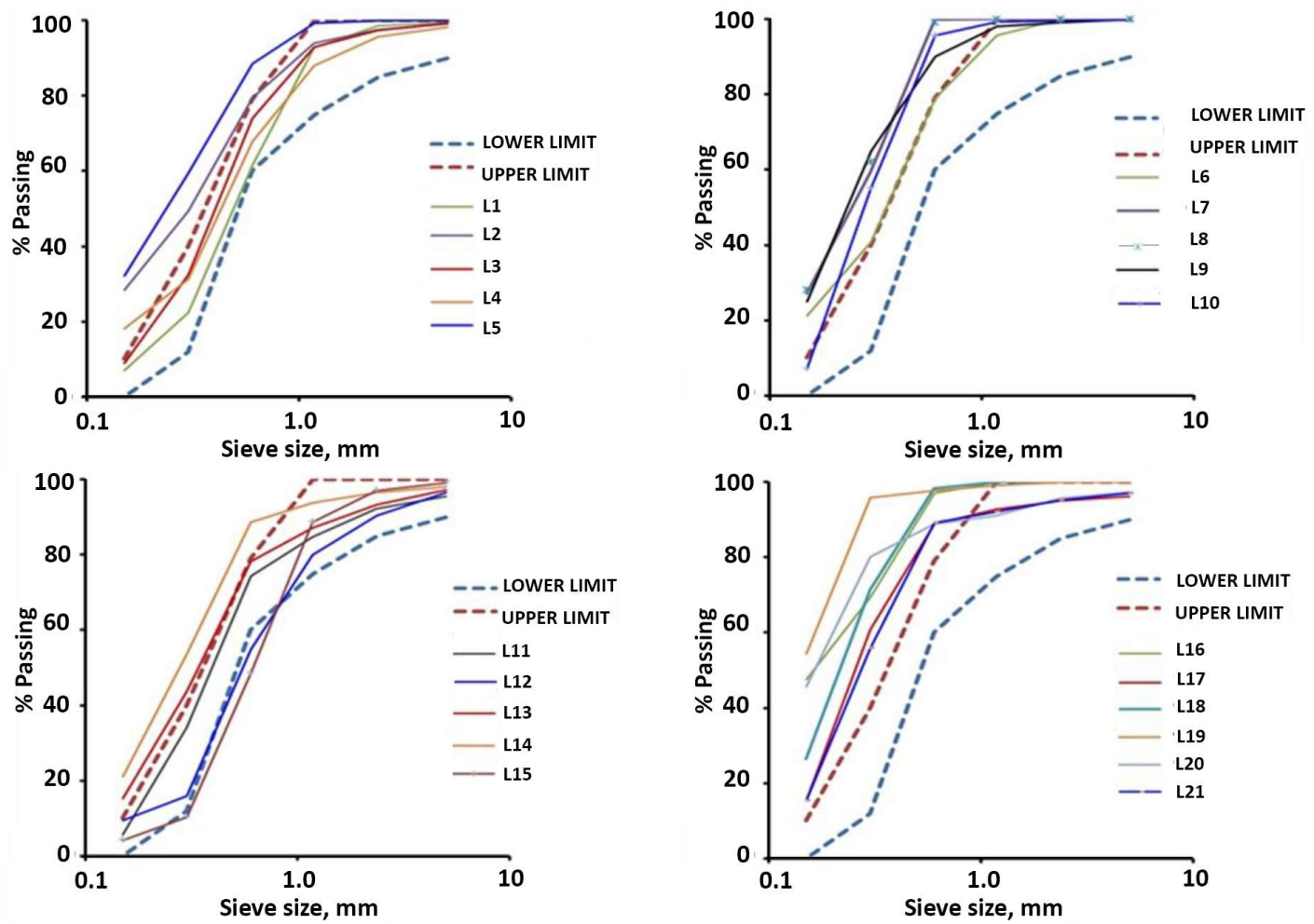

Fig. 7: Grain size distribution of the sample from the Budhi Gandaki-Narayani River compared for floor screeding BS 1199 (1986) 

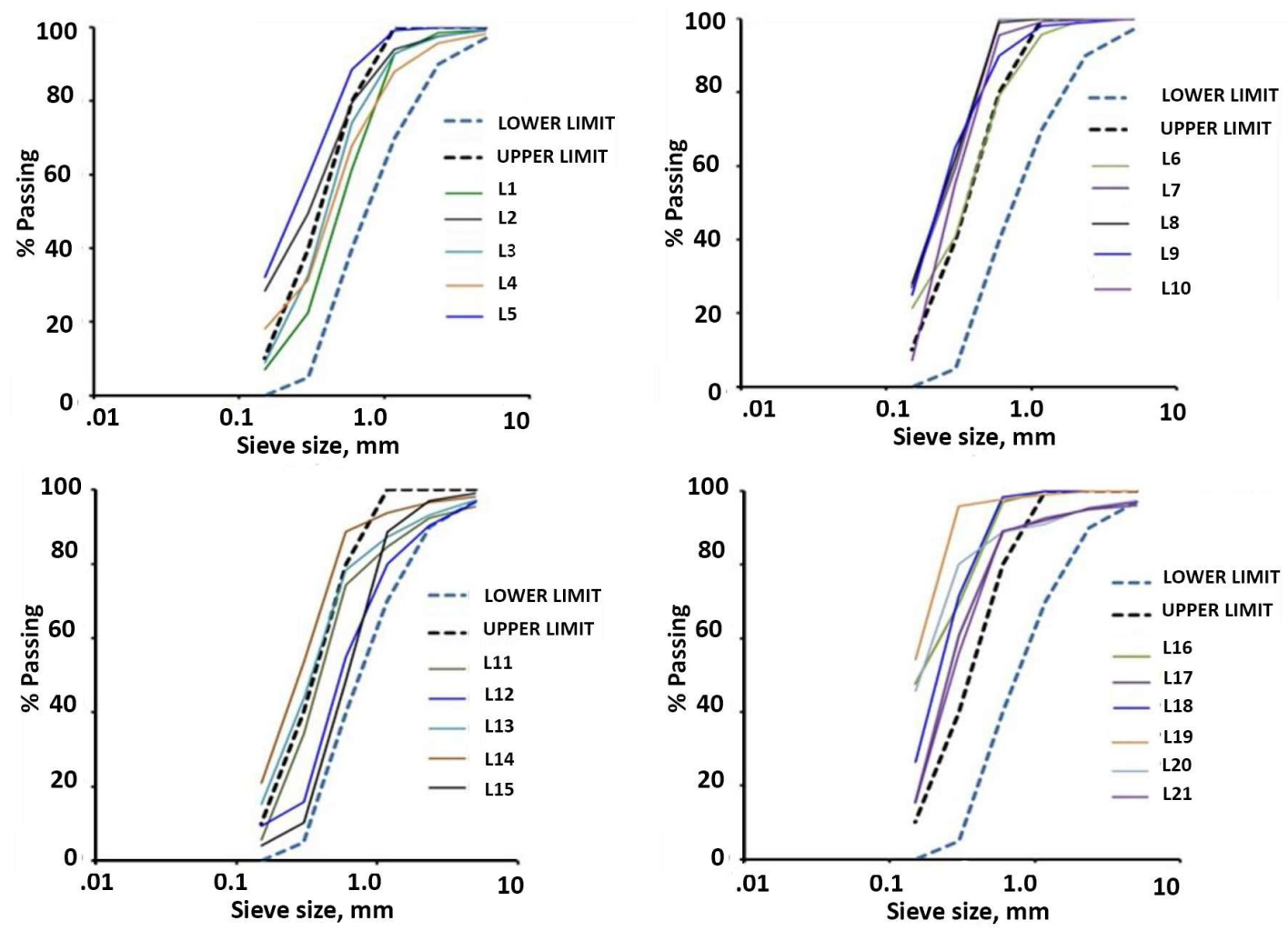

Fig. 8: Grain size distribution curve of the sample from Budhi Gandaki-Narayani River compared for external rendering with the gradation of curve of BS 1199 (1976)
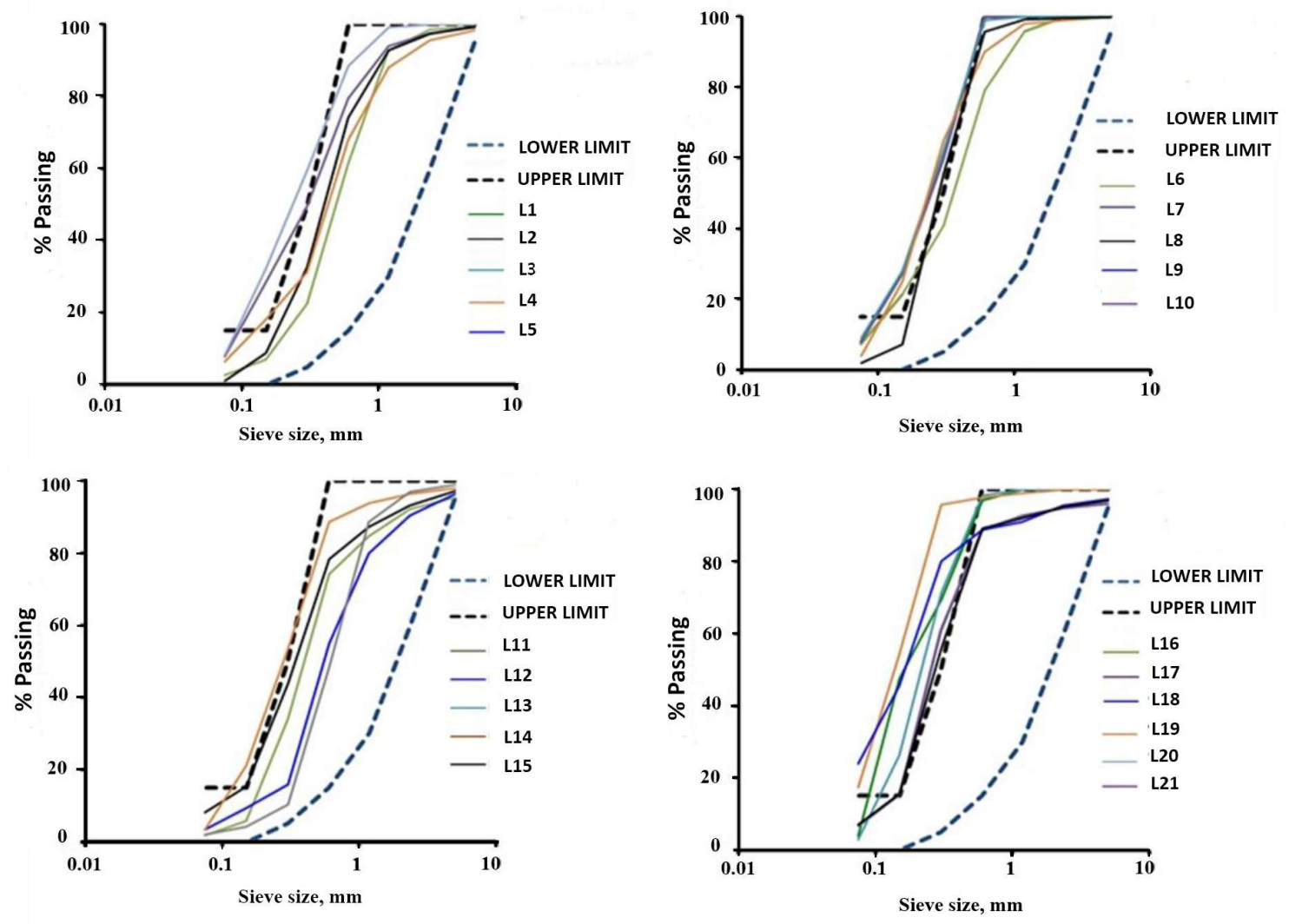

Fig. 9: Grain size distribution curve of the sample from the Budhi Gandaki-Narayani River compared for plastering with the gradation curve of BS 1199 (1986) 
Table 6: Results of analyses of physical properties of fine aggregates from the Budhi Gandaki-Narayani River

\begin{tabular}{|c|c|c|c|c|c|c|c|c|}
\hline $\begin{array}{c}\text { Sample } \\
\text { No. }\end{array}$ & $\begin{array}{l}\text { Mass } \\
\text { of Dry } \\
\text { Sand } \\
(\mathrm{gm})\end{array}$ & $\begin{array}{c}\text { Mass of } \\
\text { pyconometer } \\
\text { with water } \\
(\mathrm{gm})\end{array}$ & $\begin{array}{c}\text { Mass of pyconometer } \\
\text { filled with water and } \\
\text { sand (gm) }\end{array}$ & $\begin{array}{l}\text { Mass of sand } \\
\text { in Saturated } \\
\text { Surface Dry } \\
\text { (gm) }\end{array}$ & $\begin{array}{c}\text { Dry } \\
\text { Specific } \\
\text { gravity }\end{array}$ & $\begin{array}{c}\text { Apparent } \\
\text { Specific } \\
\text { gravity }\end{array}$ & $\begin{array}{c}\text { Dry } \\
\text { density } \\
\left(\mathrm{gm} / \mathrm{cm}^{3}\right)\end{array}$ & $\begin{array}{c}\text { Water } \\
\text { absorption } \\
(\%)\end{array}$ \\
\hline L1 & 50 & 140 & 172 & 60 & 1.82 & 2.84 & 1.76 & 1.19 \\
\hline L2 & 50 & 140 & 172 & 60 & 1.81 & 2.86 & 1.79 & 0.94 \\
\hline L3 & 48 & 140 & 168 & 55 & 1.83 & 2.48 & 1.78 & 0.47 \\
\hline L4 & 45 & 140 & 172 & 60 & 1.64 & 3.59 & 1.61 & 1.61 \\
\hline L5 & 46 & 140 & 169 & 63 & 1.48 & 2.70 & 1.35 & 1.29 \\
\hline L6 & 48 & 140 & 169 & 60 & 1.55 & 2.51 & 1.55 & 0.74 \\
\hline L7 & 44 & 140 & 167 & 63 & 1.29 & 2.63 & 1.22 & 0.61 \\
\hline L8 & 49 & 140 & 170 & 59 & 1.73 & 2.66 & 1.69 & 1.53 \\
\hline L9 & 50 & 140 & 167 & 55 & 1.80 & 2.28 & 1.79 & 0.68 \\
\hline L10 & 46 & 140 & 170 & 60 & 1.51 & 2.92 & 1.53 & 2.41 \\
\hline L11 & 47 & 140 & 168 & 55 & 1.75 & 2.59 & 1.74 & 0.57 \\
\hline L12 & 45 & 140 & 165 & 52 & 1.77 & 2.30 & 1.67 & 1.04 \\
\hline L13 & 48 & 140 & 166 & 53 & 1.89 & 2.22 & 1.78 & 1.35 \\
\hline L14 & 45 & 140 & 167 & 54 & 1.75 & 2.54 & 1.67 & 1.62 \\
\hline L15 & 46 & 140 & 165 & 58 & 1.40 & 2.21 & 1.39 & 1.30 \\
\hline L16 & 44 & 140 & 165 & 56 & 1.42 & 2.32 & 1.42 & 0.87 \\
\hline L17 & 49 & 140 & 167 & 57 & 1.65 & 2.24 & 1.63 & 1.51 \\
\hline L18 & 44 & 140 & 169 & 57 & 1.61 & 2.91 & 1.57 & 0.48 \\
\hline L19 & 42 & 140 & 164 & 54 & 1.46 & 2.33 & 1.41 & 1.26 \\
\hline L20 & 45 & 140 & 168 & 56 & 1.67 & 2.61 & 1.61 & 2.87 \\
\hline L21 & 48 & 140 & 165 & 54 & 1.79 & 2.15 & 1.66 & 1.64 \\
\hline
\end{tabular}

is below $2 \%$ which is less than standard $3 \%$. According to the specification of BS 812-2 (1995), WA should be $<3 \%$ for overall uses of aggregates. AASHTO T 85 (1982) specifies WA $<5 \%$ for the general-purpose mortar and concrete, but ASTM C 127 (2001) has specified that this should be $<2.5 \%$ for fine aggregates to be used for concrete and within $3 \%$ for tilter media.

After performing different compositional and textural analyses and physical tests, fine aggregates of the Budhi GandakiNarayani River are in overall good for plastering, rendering and floor screeding.

\section{CONCLUSIONS}

The following conclusions can be drawn out from the present study:

1.The study of the fine aggregates from the Budhi Gandaki-Narayani River shows that the fine aggregates are dominated by quartz (51-61\%) and subordinated by rock fragments (marble, meta-sandstone, schist, granite, gneiss, etc.) and other minor mineral constituents from the Himalayan rocks and sediments.

2.Mineral grains are sub-rounded to sub-angular with rough to smooth surface texture so the workability of fine aggregates is good in view of textural attribute. The degree of particles roundness and sphericity both tend to increase with transport distance.

3. Fineness modulus indicates that, very fine to coarse grain particle sizes are widely exposed along the river. The Gradation of fine aggregates shows, mostly uniform and gap graded while some are dense graded. Uniform to gap graded aggregates require blending for good results in structures.

4. The trend of presence of deleterious materials such as mica, clay lump, wood fragment, shale, and organic matter as well as carbon percentage is continuously increasing towards southern plane. Removing deleterious constituents by benefication and blending for gap graded aggregates are recommended.

5.The Budhi Gandaki-Narayani River carries light to heavy sediments, and therefore can be used in any constructional purpose from light to heavy engineering design.

6.The Budhi Gandaki-Narayani River is a good source of sand for constructional purpose like general purpose, plastering, rendering and screeding. In light of purpose of use, the suitable sample sites can be as given below:

a. For general purpose: Sands from locations L1 (Macchakholagau), L3 (Arukhet bazar), L4 (Arughat 
Table 7: Evaluation of fine aggregates from the Budhi-Gandaki-Narayani River

\begin{tabular}{|c|c|c|c|c|c|c|c|c|c|}
\hline \multirow{2}{*}{$\begin{array}{c}\text { Sample } \\
\text { No. }\end{array}$} & \multicolumn{4}{|c|}{ GRADATION BS } & \multirow{2}{*}{$\begin{array}{l}\text { Density } \\
\left(\mathrm{gm} / \mathrm{cm}^{3}\right)\end{array}$} & \multirow{2}{*}{$\begin{array}{c}\text { Quartz } \\
(\%)\end{array}$} & \multirow{2}{*}{$\begin{array}{l}\text { *Deleterious } \\
\text { constituents }\end{array}$} & \multirow{2}{*}{$\begin{array}{c}\text { **Organic } \\
\text { matter }\end{array}$} & \multirow{2}{*}{$\begin{array}{c}* * * \% \text { Water } \\
\text { absorption }\end{array}$} \\
\hline & Plastering & Rendering & Screeding & $\begin{array}{l}\text { General } \\
\text { Purpose }\end{array}$ & & & & & \\
\hline L1 & $\sqrt{ }$ & $\sqrt{ }$ & $\sqrt{ }$ & $\sqrt{ }$ & Heavy & 61.03 & Low & 0.57 & 1.19 \\
\hline $\mathrm{L} 2$ & & & & & Heavy & 60.19 & Low & 0.60 & 0.94 \\
\hline L3 & $\sqrt{ }$ & $\sqrt{ }$ & $\sqrt{ }$ & $\sqrt{ }$ & Heavy & 59.18 & Low & 0.64 & 0.47 \\
\hline L4 & $\sqrt{ }$ & $\sqrt{ }$ & $\sqrt{ }$ & $\sqrt{ }$ & Heavy & 60.01 & Low & 0.64 & 1.61 \\
\hline L5 & & & & & Normal & 57.77 & Low & 0.65 & 1.29 \\
\hline L6 & & $\sqrt{ }$ & $\sqrt{ }$ & $\sqrt{ }$ & Normal & 58.99 & Low & 0.67 & 0.74 \\
\hline L7 & & & & & Normal & 55.55 & Low & 0.70 & 0.61 \\
\hline L8 & & & & & Normal & 57.85 & Low & 0.74 & 1.53 \\
\hline L9 & & & & & Normal & 56.80 & Low & 0.75 & 0.68 \\
\hline L10 & $\sqrt{ }$ & & & $\sqrt{ }$ & Normal & 54.88 & Low & 0.77 & 2.41 \\
\hline L11 & $\sqrt{ }$ & $\sqrt{ }$ & $\sqrt{ }$ & $\sqrt{ }$ & Normal & 55.05 & Low & 0.79 & 0.57 \\
\hline $\mathrm{L} 12$ & $\sqrt{ }$ & & $\sqrt{ }$ & $\sqrt{ }$ & Normal & 52.12 & Low & 0.84 & 1.04 \\
\hline L13 & $\sqrt{ }$ & $\sqrt{ }$ & & $\sqrt{ }$ & Normal & 54.59 & Low & 0.87 & 1.35 \\
\hline L14 & $\sqrt{ }$ & & & $\sqrt{ }$ & Normal & 54.23 & Low & 0.90 & 1.62 \\
\hline L15 & $\sqrt{ }$ & $\sqrt{ }$ & & $\sqrt{ }$ & Normal & 53.41 & Low & 0.92 & 1.30 \\
\hline L16 & & & & & Normal & 55.31 & Low & 0.95 & 0.87 \\
\hline L17 & $\sqrt{ }$ & & & $\sqrt{ }$ & Normal & 53.35 & Moderate & 0.97 & 1.51 \\
\hline L18 & & & & & Normal & 54.01 & Moderate & 1.01 & 0.48 \\
\hline L19 & & & & & Light & 52.21 & Moderate & 1.04 & 1.26 \\
\hline L20 & & & & & Light & 51.04 & Moderate & 1.06 & 2.87 \\
\hline $\mathrm{L} 21$ & $\sqrt{ }$ & & & $\sqrt{ }$ & Light & 52.72 & High & 1.11 & 1.64 \\
\hline
\end{tabular}

Specification:

*Deleterious constituents ASTM C33-03: $<1$ (Low); $1 \geq$ Moderate $\leq 2$; $\geq 2$ (High);

** Organic matter (Walkey and Black, 1934): $<1$ (Low) $1>$ Moderate $<2 ;>2$ (High);

***Water absorption ASTM C 127 (2001): $<1$ (Low);1 $\geq$ Moderate $\leq 3 ; \geq 3$ (High)

bazar), L6 (Borlang), L10 (Ghayalchock), L11 (Benighat), L12 (Jogimare), L13 (Darechock), L14 (Kurintar), L15 (Mugling), L17 (Dashdhunga), and L21 (Meghauli) are good as British Standard 1299 (1984).

b. For plastering: Sands from sample locations L1 (Macchakholagau), L3 (Arukhet bazar), L4 (Arughat bazar), L10 (Ghyalchock), L11(Benighat), L12 (Jogimare), L13 (Darechock), L14 (Kurintar), L15 (Mugling), L17 (Dashdunga), and L21 (Meghauli) are good as British Standard 1199 (1986).

c. For rendering: Sands from sample locations of L1 (Macchakholagau), L3 (Arukhet bazar), L4 (Arughat bazar), L6 (Borlang), L11 (Benighat), L12 (Jogimare), L13 (Darechock), and L15 (Mugling) are best as British Standard 1199 (1976).

d. For screeding: Sands from locations L1 (Macchakholagau), L3 (Arukhet bazar), L4 (Arughat bazar), L6 Borlang), L10 (Ghayalchock), and L11

(Benighat), are very good as British Standard 882 (1973).

\section{REFERENCES}

AASHTO, 1982, Specific gravity and Absorption of coarse aggregate, Standard No.T85-81, Standard Specifications for Transportation Materials and Methods of Sampling and Testing (PartII), the American Association of State
Highway and TransportOfficials (AASHTO), pp. 266.

AASHTO M-132, 1987, Standard specification for terms relating to density and specific gravity of solids, liquids and gases. The American Association of State Highway and Transport Officials, pp. 1-4.

ASTM C 33-03, 1994, Standard Specification for Concrete Aggregates, pp.1-11.

ASTM C 127-01, 2001, Standard Test Methods for Density, Relative Density (Specific Gravity), and Absorption of Fine Aggregate ASTM International, West Conshochocken PA, pp. 1-6.

ASTM C 33-02, 2002, Standard Specification for Concrete Aggregates, ASTM International, West conshocken, PA, pp. $1-11$.

ASTM C 136-06, 2006, "Standard Test Method for Sieve Analysis of Fine and Coarse Aggregates," ASTM International, West Conshohocken, 5p.

BS (British Standards Institution) 882, 1973, Specification for aggregates from natural sources for concrete (including grano-lithic)

BS (British Standard Institution)1198, 1976, Sand for internal plasters with gypsum plaster, pp.120-141. 
BS (British Standard Institution) 1199, 1976, Sands for external rendering, internal plastering with lime and Portland cement, and floor screeds, pp.153-76.

CCAA (Cement Concrete and Aggregates Australia), 2007, Manufactured Sand national test methods and specification values, Research Report. 84p.

CCAA (Cement Concrete and Aggregates Australia), 2008, Guide to the Specification and Use of Manufactured Sand in Concrete, CCAA T60. New South Wales, 15p.

DMG (Department of Mines and Geology), 1987, Geological map of central Nepal in 1:2,50000 scale. Published by the DMG.

Dumitru, I., Song, T., Bornstein, B., and Sirivivatnanon, V., 2015, Constraints in Using Manufactured Sands in Concrete Pavements in Australia. Journal of Civil Engineering and Architecture, v. 9, pp.1318-1324. doi: 10.17265/1934-7359/2015.11.006

Fookes, P.G. and Revie, W.A., 1982, Mica in concrete-a case history from Eastern Nepal. Concrete, V. 16, No. 3, pp.12-16.

Galloway, J. E. Jr., 1994, Grading, shape, and Surface properties, American Society for Testing and Materials Special Technical Publication No. 169C, Philadelphia, PA, pp. 401-410.

Maharjan, S. and Tamrakar, N.K., 2007, Study of Gravel of the
Narayani and Rapti River for Construction Materials. Bulletin of Department of Geology, T.U., v. 10, pp. 99-106. doi: 10.3126/bdg.v10i0.1425

Smith, M.R., and Collis, L., 1993, Sand, Gravel and Crushed Rock Aggregates for Construction Purpose, Geo. Soc. London, Special Publication, v. 9, 263p.

Stöcklin, J., 1981, Geology of Nepal and its regional Frame. Journal of the Geological Society of London, 137, pp. 1-34. https://doi.org/10.1144/gsjgs.137.1.0001

Tamrakar, N.K., 2011a, Petrography of fine aggregates from Kali Gandaki River, Western Nepal: Implication for assessment of deleterious material. Bulletin of Department of Geology, Tribhuvan University, Nepal, v. 14, pp. 29-34.https://doi.org/10.3126/bdg.v14i0.5436

Tamrakar, N.K., 2011b, Pratical Sedimentology. Bhrikuti Academic Publications, Kathmandu, Nepal, 232p.

Walkey, A. and Black, I.A., 1934, Determination of organic carbon in soils. Soil Science, v. 37, pp. 29-38. https://doi.org/10.1097/00010694-193401000-00003

Walkey, A., 1935, An examination of methods for determining organic carbon and nitrogen in soils. Journal Agricultural Science, v. 25, pp. 598-609. https://doi.org/10.1017/S0021859600019687

Zafir, N. and Majid, A., 2000, The influence of aggregates properties on strength of concrete, Series on K-economy, Civil and Structural Engineering Works, Malayasia, pp. $1-22$. 
